\title{
KEKERASAN SIMBOLIK PADA RUBRIK MODE DAN CANTIK MAJALAH FEMINA
}

\author{
Ahmad Wahyudin \\ Fakultas Bahasa dan Seni \\ Universitas Negeri Yogyakarta \\ ahmadwahyudin@uny.ac.id
}

\begin{abstract}
ABSTRAK
Tujuan penelitian ini adalah mendeskripsikan wacana yang berpotensi menjadi kekerasan simbolik pada rubrik mode dan cantik majalah Femina. Subjek penelitian ini adalah semua peristiwa bahasa yang terdapat pada rubrik mode dan cantik majalah Femina edisi Juli 2014. Data diperoleh dengan teknik baca dan catat. Data dianalisis dengan teknik analisis deskriptif kualitatif. Sebuah wacana hadir tidak secara alamiah, ada kepentingankepentingan tertentu di dalamnya. Ada wacana yang sengaja diciptakan oleh kelopok kelas atas untuk mempengaruhi kelompok kelas bawah. Berbagai kebiasaan kelompok kelas atas diperkenalkan untuk mempengaruhi kelompok kelas bawah. Kekerasan simbolik akan terjadi ketika kelompok kelas bawah mengikuti kebiasaan kelas atas. Beikut ini wacanawacana yang berpotensi menjadi kekerasan simbolik pada rubrik mode dan cantik majalah Femina: 1) wacana gaya hidup konsumtif, 2) wacana pemakaian barang-barang bermerek, 3) wacana tentang penampilan: kecantikan wajah dan gaya bepakaian (fashion), 4) wacana kecantikan yang berorientasi pada model internasional.
\end{abstract}

Kata kunci: kekerasan simbolik, rubrik mode dan cantik, majalah Femina

\section{THE SYMBOLICAL VIOLENCE IN THE FASHION AND BEAUTY RUBRIC, FEMINA MAGAZINE}

\begin{abstract}
This research aims to describe the discourses that potentially turn to be symbolical violence in the fashion and beauty rubric of Femina magazine. The subject of this research is all speech events found in the rubric of Femina of July 2014 edition. The data were obtained using reading and writing technique. The data were analyzed by applying descriptive qualitative technique. A discourse does not naturally exist, but there are some interests behind it. Some discourses are created purposefully by upper class people to influence those of the lower class. Some habits of the upper class are introduced to influence the lower class people. Symbolical violence happens when the lower class people follow the habit. The followings are the discourses that potentially become the symbolical violence in the fashion and beauty rubric of Femina: 1) consumptive life style, 2) branded product consumption, 3) physical appearance: facial beauty and fashion style, 4) international oriented beauty.
\end{abstract}

Keywords: symbolical violence, fashion and beauty rublic, Femina magazine

\section{PENDAHULUAN}

Pada umumnya orang akan mudah mengenali kekerasan fisik daripada kekerasan simbolik. Ketika berbicara mengenai kekerasan fisik, orang dapat saja membayangkan tentang peperangan, perkelahian, perampokan, tawuran, pembunuhan atau tindakan-tindakan anarkis lainnya yang menyebabkan kerusakan, luka atau rasa sakit pada anggota tubuh. Tindak kekerasan ini memang terjadi karena adanya bentrok fisik antara pelaku dengan korban. Salah satu dampak kekerasan fisik dapat dilihat secara secara langsung, misalnya pelaku atau korban yang mengalami trauma fisik (luka atau memar pada tubuh) atau trauma psikologis. Lain halnya dengan kekerasan simbolik, kekerasan ini 
dampaknya tidak dapat dilihat secara fisik. Luka, trauma, dan rasa takut tidak terlihat pada korban. Korban bahkan tidak merasa sakit (fisik), tidak merasa terintimidasi, dan tidak merasa dalam tekanan. Kekerasan simbolik dilakukan secara halus. Media kekerasan simbolik dapat ditemui dalam kehidupan sehari-hari, misalnya melalui film, sinetron, gambar, atau wacana dalam rubrik di media massa. Hal ini diperjelas oleh Calaguori (2010: 388-389) yang membagi kekerasan menjadi dua macam, yaitu kekerasan konkret dan kekerasan terselubung. Kekerasan konkret terlihat pada tindak kejahatan, seperti pembunuhan, pemerkosaan, penyerangan dan penyiksaan yang dilakukan secara nyata, sedangkan kekerasan terselubung atau simbolik merupakan representasi kekerasan yang disajikan melaui tontonan hiburan dalam sebuah film atau video permainan.

Konsep kekerasan simbolik dipakai untuk menjelaskan mekanisme yang digunakan kelompok kelas atas untuk memaksakan ideologi, budaya, kebiasaaan, gaya hidupnya kepada kelompok kelas bawah (Bordieau melalui Martono, 2012: 4-5). Bentuk "pemaksaan" yang dilakukan oleh kelompok dominan tidak dilakukan secara terang-terangan, misalnya melalui pendidikan, tayangan televisi, atau wacana di media massa. Masyarakat kelas bawah yang menjadi korban kekerasan secara tidak langsung "dipaksa" untuk menerima, mencoba, mempraktikkan, dan mengikuti kebiasaan kelas atas sebagai sebuah kebiasaan yang juga pantas baginya. Kekerasan simbolik sering dianggap sebagai gejala yang wajar dalam kehidupan, korban rela menjadi objek dari kekerasan ini. Mereka menerimanya begitu saja dengan lapang dada dan mau mengikuti berbagai macam kebiasaan kelas atas.

Salah satu contoh konkret kekerasan simbolik pernah terjadi di China pada tahun 2012. Seorang pemuda di China rela menjual ginjalnya hanya untuk membeli iPad dan iPhone. Wang, pemuda berusia 17 tahun melakukan transplantasi ginjal ilegal setelah dia mendapat informasi dari internet. Para pelaku transplantasi memberi Wang US\$3.000 atau sekitar Rp28 juta. Kini ia menderita gagal ginjal karena proses transplantasi ilegal tersebut. Kasus ini terungkap secara tidak sengaja saat ibu
Wang mendapati anaknya memiliki beberapa gadget baru yang harganya cukup mahal bagi kalangan kelas bawah. Saat ditanya dari mana Wang memperoleh uang untuk membeli gadget itu, dia mengaku telah menjual salah satu ginjalnya. iPhone dan iPads adalah gadget pintar produksi Apple sangat populer di China, sayangnya harga keduanya terbilang mahal untuk warga China pada umumnya (BBC Indonesia, 2012). Wang dapat dikatakan sebagai salah satu korban kekerasan simbolik dari sebuah produk karena ia berusaha untuk mengikuti kebiasaan kelas atas yang menggunakan gadget tersebut. Informasi mengenai produk tersebut bisa di dapatkan dari media massa, misalnya rubrik yang mengulas tentang gaya hidup kelas atas yang menggunakan produk tersebut.

Kekerasan simbolik dapat ditemui di berbagai macam media, misalnya pada majalah khusus wanita Femina. Majalah ini sudah ada sejak tahun 1972 dan termasuk dalam 12 media besar di Indonesia (Wahyu, 2013). Segmen pembaca majalah ini adalah para remaja, ibu rumah tangga, dan wanita pekerja. Ini berarti siapa saja dapat membaca majalah ini, baik itu kelas sosial bawah, menengah, maupun atas. Majalah ini memiliki rubrik khusus yang menyajikan tentang gaya hidup dan kecantikan. Rubrik tersebut adalah rubrik mode dan cantik. Dalam rubrik ini, misalnya sosok perempuan ideal secara fisik digambarkan dengan tubuh yang langsing, putih, rambut lurus, dan bebas dari bulu kaki atau ketiak. Selain menampilkan gambar perempuan ideal dari segi fisik, rubrik ini juga disisipi iklan. Misalnya, salah satu iklan membuat pernyataan untuk mempengaruhi para calon konsumen dengan membuat pernyataan bahwa "cantik itu putih", "cantik itu kulit mulus tanpa bulu". Rubrik dan iklan ini dapat dibaca oleh siapa saja, baik itu kelas bawah, menengah, dan atas. Akibatnya, wacana tersebut bagi sebagian perempuan (kelas bawah, menengah, dan atas) dijadikan standar sebagai sosok wanita ideal sehingga ada sebagian wanita berusaha dengan berbagai macam cara untuk menjadi sosok perempuan ideal tersebut. Dengan bahasa yang telah terdistorsi dan adanya unsur "kekuasaan" kelas atas/pemilik modal, ada orang-orang kelas bawah berusaha mengikuti gaya hidup kelas dominan. Misalnya, mereka 
membeli berbagai macam alat kecantikan, obat pelangsing, melakukan sedot lemak, bahkan mengubah bagian tubuhnya dengan suntik silikon atau operasi plastik seperti yang dilakukan oleh kelas atas. Golongan kelas bawah yang dengan berbagai macam cara berusaha memenuhi standar wanita ideal sebagaimana yang telah dicitrakan oleh media merupakan salah satu korban kekerasan simbolik, kecuali mereka yang menggunakan cara yang alami, tidak berlebihan dan wajar untuk mencapainya. Pencitraan itu secara tidak langsung memaksakan sebuah kebiasaan, standar, budaya yang dianggap paling tepat untuk para pembacanya.

Untuk membahas hal tersebut, analisis wacana kritis diperlukan untuk mengidentifikasi bentuk-bentuk kekerasan simbolik di media massa. setiap wacana yang diproduksi (tulis atau lisan) tidak dipandang sebagai suatu yang alamiah, wajar, dan netral karena ada elemen kekuasaan di dalamnya (Eriyanto, 2001: 12). Analisis wacana kritis tidak hanya sekedar mengungkap struktur atau isi dari wacana, tetapi juga menghubungkan dengan kekuatan dan kondisi sosial, politik, ekonomi, dan budaya. Harahap (2013: 34) juga menjelaskan bahwa komunikasi dapat dimanfaatkan oleh kelas yang berkuasa, baik untuk mempertahankan kekuasaannya maupun merepresif pihak-pihak yang menentangnya. Bahasa dalam sebuah rubrik bukanlah bahasa yang alamiah karena didalamnya ada kepentingan kekuasaan (ekonomi). Oleh karena itu, aspek-aspek kekuasaan yang muncul pada sebuah wacana perlu diungkap dan dikritisi. Wacana-wacana yang berpotensi menjadi bentuk kekerasan simbolik juga perlu diungkap.

\section{METODE PENELITIAN}

Desain penelitian ini adalah penelitian deskriptif kualitatif, yaitu suatu penelitian yang bertujuan untuk mendeskripsikan gambaran ciriciri data secara akurat sesuai dengan sifat alamiah data itu sendiri (Djajasudarma, 2006: 16). Penelitian ini bertujuan untuk mendeskripsikan bentuk kekerasan simbolik pada rubrik mode dan cantik majalah Femina.

Subjek dalam penelitian ini adalah semua peristiwa bahasa yang terdapat pada rubrik mode dan cantik majalah Femina. Penelitian ini dilakukan sebagai upaya untuk mendeskripsikan fenomena kekerasan simbolik berdasarkan fakta-fakta penggunaan bahasa apa adanya secara sinkronik. Istilah sinkronis yang dimasudkan di sini adalah mengkaji dan memerikan fenomena pada wacana dalam kurun waktu tertentu dengan tujuan tertentu. Objek dalam penelitian ini adalah simbol-simbol kekerasan simbolik pada rubrik mode dan cantik majalah Femina.

Instrumen utama dalam penelitian ini adalah peneliti sendiri (human instrument). Dalam hal ini peneliti dituntut memiliki kemampuan dan pengetahuan tentang hal-hal yang berkaitan dengan masalah penelitian. Artinya, peneliti harus peka, mampu, logis, dan kritis karena bertindak sebagai perencana, pelaksana, pengambil data, penganalisis, sekaligus sebagai pelapor hasil penelitian.

Instrumen lain yang digunakan dalam penelitian ini adalah berupa perangkat keras dan perangkat lunak. Perangkat keras berupa alat tulis dan komputer untuk mencatat bentukbentuk kekerasan simbolik kekerasan simbolik pada rubrik mode dan cantik majalah Femina. Perangkat lunak berupa kriteria-kriteria yang

Tabel 1. Indikator Kekerasan Simbolik

\begin{tabular}{|c|l|}
\hline Definisi & $\begin{array}{l}\text { Mekanisme yang digunakan kelompok kelas atas untuk memaksakan } \\
\text { ideologi, budaya, kebiasaan, gaya hidupnya kepada kelompok kelas bawah } \\
\text { secara halus untuk kepentingan tertentu. }\end{array}$ \\
\hline Pelaku & Kelompok kelas atas atau pemilik modal yang mempunyai kekuasaan. \\
\hline Korban & Kelompok kelas bawah. \\
\hline Modus & $\begin{array}{l}\text { Memperkenalkan/menampilkan/menunjukkan berbagai habitus kelompok } \\
\text { kelas atas melalui berbagai macam wacana untuk mempengaruhi kelompok } \\
\text { kelas bawah dengan cara halus sehingga mereka tidak menyadari bahwa } \\
\text { dirinya menjadi objek dari kekerasan ini. }\end{array}$ \\
\hline Media & Lisan, tulis, gambar \\
\hline Tujuan & Ekonomi, kekuasaan, politik \\
\hline
\end{tabular}


telah ditentukan berdasarkan teori-teori yang telah dibahas dalam kajian pustaka.

Berdasarkan data penelitian yang berupa wacana tulis tersebut, penyediaan data dilakukan dengan metode catat dan simak. Metode simak yang disejajarkan dengan metode pengamatan atau observasi pada penelitian sosial digunakan untuk memperoleh data yang dilakukan dengan cara menyimak. Seperti yang dinyatakan oleh Mahsun (2005: 90) dalam kaitannya dengan metode simak bahwa istilah menyimak tidak hanya berkaitan dengan penggunaan bahasa secara lisan, tetapi juga penggunaan bahasa secara tertulis. Melalui metode ini, semua bentuk bahasa yang digunakan pada rubrik mode dan cantik majalah Femina dibaca dengan seksama untuk menentukan bentuk-bentuk kekerasan simbolik pada majalah Femina edisi Juli 2014. Di dalam kegiatan pembacaan dilakukan kegiatan pencatatan (mentranskrip) untuk mendokumentasikan data yang diperoleh dan dicatat pada lembar berkolom.

Dari penyediaan data tersebut, kemudian dilakukan pengidentifikasian, dan dari hasil identifikasi sebagai data kualitatif selanjutnya dilakukan pemilahan untuk membuat klaisifikasi data. Berdasarkan klasifikasi yang sangat kaya dan dalam bentuk aslinya tersebut kemudian dianalisis untuk memperoleh interpretasi atas temuan-temuan secara deskriptif.

Teknik analisis data yang digunakan dalam penelitian ini adalah teknik padan. Metode padan adalah metode analisis bahasa sebagai alat penentunya di luar, terlepas, dan tidak menjadi bagian dari bahasa yang bersangkutan. Kriteria dalam metode padan digunakan dalam adalah sebagai berikut (Sudaryanto, 2001: 13-16).

Teknik pada referensial digunakan untuk mengetahui satuan gramatikal kekerasan simbolik. Teknik padan referensial melalui pendekatan semantik untuk mengetahui makna kekerasan simbolik.

Teknik padan pragmatik digunakan untuk menganalisis latar belakang penggunaan kekerasan simbolik. Teknik yang digunakan adalah teknik kategorisasi. Teknik kategorisasi ini dilakukan untuik mengategori segala sesuatu yang peneliti temukan dalam peristiwa tutur sesuai dengan teori kekerasan simbolik.
Agar data yang dikumpulkan itu benarbenar merupakan data yang baik, maka diperlukan pemeriksaan keabsahan data. Teknik penentuan keabsahan data dalam penelitian ini dilakukan dengan cara sebagai berikut.

Validitas data yang digunakan dalam penelitian ini adalah validitas semantik, yaitu dengan cara menafsirkan data dengan mempertimbangkan makna keseluruhan bentuk-bentuk kekerasan simbolik dengan mengikutsertakan konteksnya.

\section{Reliabilitas}

Reliabilitas merupakan teknik pemeriksaan data yang memanfaatkan sesuatu yang lain di luar data tersebut untuk keperluan pengecekan, artinya bahwa keabsahan data tersebut didukung oleh faktor-faktor yang saling berhubungan antara informan atau data hasil penelitian yang satu dengan yang lain mempunyai kecocokkan serta pertimbangan-pertimbangan lain untuk mendukung bahwa data tersebut sah atau benar. Dalam penelitian ini, reliabilitas yang digunakan adalah sebagai berikut.

\section{Intrarater}

Inrarater dilaksanakan untuk mendapatkan keabsahan data. Intrareter dilakukan dengan cara mencermati kembali data yang tersedia secara berulang-ulang untuk menemukan data sebanyak-banyaknya dan aspek-aspek yang relevan dengan permasalahan yang diteliti sehingga didapatkan data yang benar-benar akurat.

\section{Interater}

Selain intrarater, keabsahan data juga diperoleh secara interater yaitu dengan berdiskusi dengan rekan sejawat dan bertanya kepada orang yang lebih ahli di bidangnya untuk mengecek kebenaran dan interpretasi yang telah dilaksanakan dalam penelitian.

\section{HASIL DAN PEMBAHASAN}

Kehadiran sebuah wacana dipandang sebagai sesuatu yang diproduksi, dimengerti, dan dapat dianalisis melalui konteks tertentu. Sebuah wacana dapat dianalisis dengan menggunakan pendekatan mikro dan makro (Gumpers, 1982). Kaitannya dengan kekerasan simbolik pada rubrik mode dan cantik majalah Femina, 
pendekatan makro dapat digunakan. Analisis makro digunakan untuk mengungkap konteks sosial budaya dari sebuah wacana yang diproduksi karena wacana bukanlah sesuatu yang alamiah, netral, dan wajar (Eriyanto, 2006: 11). Berdasarkan hal tersebut, wacana yang diproduksi oleh seseorang mengandung maksud-maksud tertentu. Ada wacana-wacana yang memang sengaja dibuat oleh kelompok kelas atas atau pemilik modal untuk tujuan tertentu. Wacana tersebut sengaja dibuat untuk mempengaruhi baik kelompok kelas atas maupun bawah. Permasalahan akan muncul ketika kelompok kelas bawah meniru kebiasaan kelas. Mereka meniru habitus kelas atas seolah tanpa paksaan dan menganggap bahwa itu juga habitus mereka. Hal inilah yang disebut kekerasan simbolik.

Penelitian mengenai kekerasan simbolik pernah dilakukan oleh oleh Martono (2012) yang berjudul Kekerasan Simbolik di Sekolah. Objek penelitian ini adalah buku sekolah elektronik (BSE). Secara lebih rinci objek yang diteliti adalah gambar dan teks. Hasil penelitian Martono menunjukkan bahwa sebagian besar kalimat dan gambar yang ada dalam buku BSE memuat habitus kelas dominan (kelas atas) seperti bertamasya, merayakan ulang tahun, meceritakan dan memperlihatkan benda-benda yang dimiliki kelas atas: wastafel, kitchen set, garasi, vacum cleaner. Selain itu, Roekhan (2010) juga pernah melakukan penelitian yang berjudul Kekerasan Simbolik di Media Massa. Data penelitian ini berupa teks berita di koran dan teks penerimaan pembaca atas pemberitaan kasus semburan lumpur di koran. Teks berita dikumpulkan dari Jawa Pos, Kompas, Suara Pembaharuan, dan Republika. Hasil penelitian Roekhan menunjukkan bahwa kekerasan simbolik di media massa meliputi: (1) makna kabur, (2) logika bias, dan (3) nilai bias. Strategi kekerasan simbolik yang digunakan meliputi: (1) penghalusan informasi, (2) pelogisan informasi, dan (3) pemositifan informasi.

Persamaan penelitian ini dengan dua penelitian yang sebelumnya adalah pada samasama mengkaji permasalahan kekerasan simbolik. Perbedaannya dengan penelitian ini adalah pada objek yang diteliti sehingga hasilnya juga berbeda. Hasil penelitian ini diharapkan juga dapat menambah khasanah pengetahuan tentang kekerasan simbolik, khususnya kekerasan simbolik pada rubrik mode dan cantik majalah Femina.

Berikut ini adalah wacana-wacana yang berpotensi menimbulkan kekerasan simbolik pada rubrik mode dan cantik majalah Femina.

\section{Wacana Gaya Hidup Konsumtif}

Salah satu simbol kekerasan simbolik pada rubrik mode dan cantik majalah Femina adalah gaya hidup konsumtif. Gaya hidup konsumtif sering dijumpai pada kehidupan golongan kelas atas. Gaya hidup ini terelialisasi pada perilaku yang ingin selalu membeli dan mempunyai sesuatu. Kadang kala barang-barang yang dibeli di luar keperluan dan kebutuhan. Oleh sebagian orang, barang-barang yang dibeli atau dimiliki digunakan untuk menunjukkan status sosial mereka. Semakin banyak yang dibeli dan dimiliki semakin tinggi status sosial mereka. Gaya hidup konsumtif kelas atas dapat dilihat pada rubrik mode dan cantik majalah Femina, misalnya pada contoh berikut ini.

(1) Jaket Natalia Kiantoro Rp 4.000.000. Atasan crop: Natalia Kiantoro Rp 700.000. Celana: Natalia Kiantoro Rp 600.000. Anting: Chloris, harga atas permintaan. Sepatu: Charles \& Keith, Rp 626.000

28-04.07.14.004

Pada penggalan wacana (1), pembaca disuguhkan dengan berbagai macam produk yang sedang dipakai oleh seorang model. Untuk dapat tampil seperti yang sedang dikenakan oleh seorang model, total uang yang harus dikeluarkan untuk membeli pakaian dan aksesorisnya kurang lebih Rp 5.926.000. Pemilik modal juga memberikan penjelasan secara detail namanama produk yang sedang dipakai dan juga dilengkapi dengan harga produk tersebut. Hal ini menjadi referensi bagi pembaca untuk dapat tampil seperti yang diperagakan oleh model tersebut sehingga tertarik untuk membeli produk tersebut. Oleh karena itu, merek produk dan harga ditulis agar para pembaca membeli produk tersebut.

Tentu ada berbagai macam alasan pembaca membeli produk tersebut, misalnya, agar 
penampilannya seperti yang diperagakan oleh model atau hanya sekedar untuk koleksi saja sehingga pembaca menjadi orang yang konsumtif. Gaya hidup seperti ini biasa dilakukan oleh golongan kelas atas.

Gaya hidup konsumtif kelas atas selalu dimunculkan pada rubrik ini. Golongan kelas atas (pemilik modal) membangun opini bahwa budaya konsumtif adalah bagian dari gaya hidup mereka, sehingga gaya hidup seperti ini menjadi sesuatu yang wajar. Kebiasaan kelas atas ini kemudian dapat saja ditiru oleh kelompok kelas bawah. Kekerasan simbolik akan muncul ketika golongan kelas bawah meniru gaya hidup golongan kelas atas tersebut. Kebiasaankebiasaan kelas atas masuk dalam habitus kelas sosial bawah. Fenomena tersebut juga menjadi keberhasilan para pengusaha atau pemilik modal mempengaruhi masyarakat untuk membeli produk-produk mereka. Gaya hidup konsumtif disisipkan pada rubrik atau iklan di media. Rubrik atau iklan tersebut dibuat semenarik mungkin, biasanya yang ditampilkan adalah habitus kelas atas. Tujuannya adalah agar masyarakat membeli produk mereka tanpa menghiraukan siapa saja yang membeli (golongan kelas atas atau bawah).

\section{Wacana Pemakaian Barang-Barang Berme- rek}

Ada berbagai macam cara yang dilakukan oleh golongan kelas atas untuk menunjukkan status sosial mereka, salah satunya adalah kepemilikan barang-barang bermerek, mewah, atau mahal. Berdasarkan riset Yajin Wang dan Vladis Griskevicius dalam Journal of Consumer Research in America (melalui Rezkisari, 2014) penggunaan barang-barang mewah atau mahal bertujuan untuk mendongkrak rasa percaya diri dan juga untuk mengekspresikan diri dan memberi sinyal terhadap status sosial tertentu. Rubrik mode dan cantik pada majalah Femina menampilkan gaya hidup seperti ini.

(2) Rompi: Natalia Kiantoro: Rp 2.500.000. Atasan tanpa lengan: Natalia Kiantoro, Rp 950.000. Rok: Natalia Kiantoro Rp 1.200.000. Kalung (kiri): Chloris, harga atas permintaan. Gelang: Chloris, harga atas per- mintaan. Tas: Charles \& Keith Rp 649.000.

Sepatu: Charles \& Keith Rp 1.099.000.

$$
\text { 28-04.07.14.007 }
$$

Wacana (2) digunakan untuk menjelaskan produk-produk yang sedang dipakai oleh seorang model pada rubrik mode dan cantik. Misalnya, Natalia Kiantoro adalah produk lokal yang sudah dikenal di dunia fashion. Nama produk ini diambil dari nama desainer dari Surabaya yang bernama Natalia Kiantoro. Selain produk dari Natalia Kiantoro, pada wacana di atas pembaca juga disuguhkan dengan aksesoris berupa gelang dengan merek Chloris dan tas bermerek Charles \& Keith. Kedua merek tersebut juga cukup terkenal dalam dunia fashion. Charles \& Keith adalah perusahaan penjual sepatu yang cukup terkenal di Singapura. Charles Wong dan Keith Wong memulai bisnis mereka pada tahun 1990 dari sebuah toko kecil penjual sepatu khusus wanita. Berbekal kesuksesan di negerinya, mereka memutuskan untuk melakukan ekspansi internasional. Indonesia adalah negara pertama yang mereka pilih untuk mengembangkan bisnisnya secara internasional pada tahun 1998. Charles \& Keith Indonesia mendirikan toko pertamanya di Ratu Plaza Indonesia. Perusahaan ini merekrut enam pabrik di Indonesia untuk memproduksi sepatu merek tersebut. Sampai sekarang perusahaan ini telah memiliki lebih dari 270 toko di lebih dari 30 negara di seluruh dunia. Pada tahun 2004, Charles \& Keith memperluas pasar dari Asia ke Timur Tengah ketika membuka toko di Dubai. Sejak saat itu, produk ini memperluas ke pasar baru di Asia, Timur Tengah, Afrika dan Eropa. Produk-produk dari Natalia Kiantaro dan Charles \& Keith merupakan produk-produk yang banyak dipakai oleh golongan kelas atas. Jika kebiasaan penggunaan barang-barang bermerek ini ditiru oleh kelompok bawah, maka kekerasan simbolik akan terjadi. Contoh lain pengunaan barang-barang bermerek juga dapat dilihat pada wacana berikut.

(3) Gaun yang dijadikan blus: Oasis, Rp 1.099.000, Sepatu: Charles \& Keith, Rp 599.000

$19-25.07 .14 .055$ 
(4) Blus: Marks \& Spencer, Rp 799.000. Rok flare: Jii, Rp 475.000. Kalung: Stradivarius, harga atas permintaan. Gelang: The Executive, Rp 89.000. Tas: Marks \& Spencer Rp 849.000. Sepatu: Marks \& Spencers, Rp 799.000

05-11.07.14.040

Berdasarkan wacana (3) dan (4), ada beberapa merek pakaian dan aksesorisnya yang dapat dijadikan referensi bagi pembaca. Oasis adalah brand fashion berasal dari UK, London. Di Indonesia produk-produk Oasis hanya dapat ditemukan di Mal Kuningan City, Debenhams, dan Sogo. Desain pada busananya juga terbilang lengkap, mulai dari blouse, sweater, jaket, mini dress, serta maxi dress. Selain Oasis, banyak retailer fashion dunia yang terkenal ditampilkan dalam rubrik ini. Brand-brand fashion yang sudah mendunia dan dikenal secara luas sengaja ditampilkan, misalnya Marks and Spencer termasuk salah satu nama retailer fashion yang terkenal. Marks \& Spencer juga dikenal dengan nama $M \& S$ adalah retailer terbesar di Inggris, City of Westminster, London. Brand ini diciptakan oleh Michael Marks dan Thomas Spencer. Pada saat ini, mereka memiliki 703 toko di Inggris dan 361 toko yang tersebar lebih dari 40 negara Mereka membuka kios pertamanya di Leeds, pada tahun 1894. Kemudian perusahaan M\&S berkembang. Tahun 1975 M\&S membuka toko-toko di daratan Eropa. Empat tahun kemudian, mereka membuka toko di Irlandia. Toko pertama di Asia Tengah milik mereka dibangun di Kabul pada tahun 1960. Sampai sekarang nama brand mereka sudah terdengar di seluruh dunia. Marks and Spencer memproduksi produk pakaian yang bergaya, berkualitas tinggi, bernilai tinggi. Mereka memperkerjakan 78.000 orang di Inggris, dan di luar negeri. Mereka memiliki lebih dari 700 toko di Inggris. Marks $\&$ Spencer merupakan provider pakaian wanita dan lingerie nomor satu di Inggris. Tidak hanya pakaian wanita, mereka juga memproduksi pakaian pria, dan pakaian anak-anak. Bisnis mereka juga melalui jalur penjualan online di internet. Untuk pakaian wanita mereka menjual produk-produk seperti lingerie, pakaian dalam, mantel, jaket, celana jeans, legging, knitwear, baju malam, rok, baju renang, baju pantai, baju olahraga, dan baju kerja (Mark \& Spencer, Brand Fashion Berkelas, 2012)

Selain Charles Keith, Oasis, dan Mark \& Spencer ditampilkan juga brand terkenal dari Spanyol yaitu Stradivarius. Brand ini berdiri sejak tahun 1994. Sasarannya adalah para wanita usia 20 hingga 35. Hingga saat ini, Stradivarius terus berkembang dan membuka cabang hingga ke 60 kota yang berpusat di Amerika Serikat. Belum lama ini, Stradivarius membuka cabang di Shopping Centre London's White City. Saat ini, Stradivarius memiliki 6.300 toko yang tersebar di 87 negara, termasuk sejumlah toko di pusat perbelanjaan terkemuka di Indonesia (Melissa, 2014).

Merek terkenal lainnya yang ditampilkan pada rubrik ini adalah The Executive. Pada tahun 1979 oleh Mr. Johanes Farial mendirikan PT. Delami Garment Industries. Industri ini bergerak dalam bidang manufaktur dengan memproduksi celana panjang pria untuk pasar domestik. Pada tahun 1984, perusahaan mengambil alih merek Executive 99, pada saat itu merek ini sebagai pemimpin pasar dalam kategori celana pria. PT. Delami menjadi salah satu produsen terkemuka di Indonesia garmen. The Executive atau yang lebih dikenal dengan Executive 99 menyediakan berbagai pakaian resmi pria dan wanita dengan berbagai aksesoris pendukungnya. Model, potongan baju, dan celana yang anggun dan menawan serta pemakaian bahan yang lembut serta nyaman di pakai membuat Executive 99 produk yang selalu dicari para pekerja kantoran dan yang menginginkan tampil rapi (The Executive, 2012)

Kebiasaan menggunakan barang-barang bermerek seperti Mark \& Spencer, Charles Keith, Oasis, Stradivarius, dan The Executive adalah kebiasaan atau habitus kelas atas. Pemilik modal menampilkan kabiasaan tersebut. Simbol-simbol ini sengaja ditampilkan pada rubrik ini. Penggunaan barang-barang bermerek ditampilkan agar pembaca tertarik dengan produk tersebut, baik kelas atau maupun kelas bawah. Simbol kekerasan simbolik akan nampak terlihat ketika pemilik modal menampilkan kebiasaan kelas atas untuk mempengaruhi kelompok kelas bawah. Permasalahan akan muncul dan menjadi bentuk kekerasan simbolik ketika kebiasaan atau 
habitus menggunakan barang-barang bermerek ini ditiru oleh golongan kelas bawah.

\section{Wacana tentang Penampilan}

Penampilan dalam hal ini adalah sesuatu yang berhubungan dengan penampilan fisik seseorang, seperti wajah, rambut, bentuk tubuh, kaki, dan sebagainya. Penampilan ini mudah diamati dan dinilai oleh orang-orang di sekitar. Bagi sebagian orang penampilan menjadi hal yang paling utama dalam kehidupannya. Berbagai macam cara digunakan oleh seseorang dilakukan orang untuk tampil menawan atau cantik.

Penampilan bagi golongan kelas atas tidak hanya ditunjang dari segi pakaian saja, namun pada bagian tubuh dan muka pun harus diperhatikan agar penampilan mereka tetap cantik. Pihak media memanfaatkan habitus kelas atas ini menjadi sebuah rubrik. Tujuan mereka tidak lain adalah menawarkan produk-produk untuk dijual kepada semua golongan. Wacana mengenai penampilan meliputi wacana tentang kecantikan wajah dan gaya berpakaian.

\section{Wacana tentang Kecantikan Wajah}

Nilai kecantikan sangat relatif, tergantung dari sudut mana orang memandang. Paling tidak ada dua macam kecantikan, yaitu kecantikan luar dan dalam. Kecantikan luar adalah kecantikan yang dapat dilihat oleh mata, seperti wajah, kulit, kuku, rambut, bentuk tubuh, dan sebagainya. Berbeda dengan kencantikan luar yang dapat dilihat mata secara langsung, kecantikan dalam berhubungan dengan kepribadian dan tingkah laku. Seseorang dikatakan memiliki kecantikan dalam jika memiliki kepribadian dan tingkah laku yang baik.

Dalam praktiknya, banyak orang yang ingin memperbaiki kecantikan fisik, misalnya wajah. Hal ini tidak dapat diingkari bahwa wajah yang cantik adalah dambaan setiap wanita. Ada berbagai macam cara dilakukan oleh seorang wanita agar terlihat cantik. Habitus ini kemudian masuk ke dalam rubrik mode dan cantik majalah Femina. Berikut ini adalah beberapa habitus kelompok kelas atas yang dilakukan untuk memperbaiki kecantikannya.

(5) Masalah: Warna kulit tidak rata dan kantong menghitam
Oleskan BB cream yang mengandung SPF 30 secara merata mulai dari pipi, dagu, bagian bawah mata, hingga leher. Pada area mata, aplikasikan concealer warna oranye dan nude. Bubuhkan bedak sesuai dengan warna kulit. Terakhir, sapukan kuas berbentuk bulat dan besar agar alas bedak membaur secara merata dengan BB cream ke seluruh permukaan wajah hingga leher. Tambahkan dengan pemakaian Funky Eyelights Pencil 13 Ever Green pada sudut mata bagian dalam.

05-11.07.14.04

Wacana (5) menggambarkan kegiatan yang dilakukan oleh kelompok kelas atas untuk memperbaiki kecantikannya. Permasalahannya yaitu warna kulit yang tidak merata dan kantong menghitam pada kelopak mata. Untuk mengatasi permasalahan itu, ada beberapa hal yang dilakukan seperti memakai BB cream yang megandung SPF, memakai concealer warna orange dan nude, dan menyapukan kuas berbentuk bulat dan besar agar alas bedak membaur secara merata dengan BB cream ke seluruh permukaan wajah hingga leher. Terakhir, tambahkan dengan pemakaian Funky Eyelights Pencil 13 Ever Green pada sudut mata bagian dalam.

(6) Masalah: Mata kecil \& sipit dan bibir tipis.

Solusi: Andalkan eye liner pensil. Caranya, aplikasikan eye liner pensil mulai dari garis mata atas bagian dalam ke sudut mata bagian luar. Pada garis mata bagian bawah, aplikasikan eye liner warna putih terlebih dahulu tepat di sela bulu mata. Lalu lapisi kembali dengan eye liner hitam menggunakan teknik cat eyes. Bibir mungil tampak lebih berisi dengan pulasan lipstick warna shocking pink.

05-11.07.14.049

Bagi sebagian orang memiliki mata kecil dan sipit serta bibir adalah sebuah permasalahan. Untuk mengatasi hal tersebut, wacana di atas hadir. Untuk mengatasi hal tersebut, pemilik mata sipit dan bibir tipis bisa menggunakan eye liner pensil mulai dari garis mata atas bagian dalam ke sudut mata bagian 
luar. Selain itu, orang dapat menggunakan eye liner warna putih terlebih dahulu tepat di sela bulu mata. Setelah itu, lapisi kembali dengan eye liner hitam menggunakan teknik cat eyes. Terakhir gunakan lipstik warna shocking pink agar bibir tampak berisi.

Kedua wacana di atas hadir untuk mengatasi permasalahan kecantikan di area wajah. Ada berbagai macam cara yang dapat dilakukan untuk mengatasi masalah kecantikan di area tersebut seperti yang sudah dijelaskan di atas. Solusi yang ditawarkan atas permasalahan tersebut merupakan habitus kelas atas. Pemilik modal dalam rubrik mode dan cantik menampilkan kebiasan-kebiasaan kelompok sosial atas dalam mengatasi berbagai macam permasahan kecantikan. Kebiasaan ini bisa saja ditiru oleh kelompok sosial bawah.

\section{Wacana Gaya Berpakaian (Fashion)}

Agar tampil cantik dan menarik, selain mempercantik area wajah, orang-orang kelas atas juga memperhatikan gaya berpakaian (fashion) mereka. Berikut ini gaya berpakaian golongan kelas atas yang ada pada rubrik mode dan cantik majalah Femina.

(7) Pemilik tubuh boyish cocok mengenakan rok berpotongan princess cut berdetail diamante. Atasan berbahan brokat serta sepatu snake skin yang memperkuat kesan mewah.

$19-25.07 .14 .054$

(8) Coba blus cropped dengan rok trompet yang menonjolkan area pinggul. Seksi! Hindari kesan kekanakan saat mengenakan jumpsuit motif polkadot dengan nuansa warna gelap

$05-11.07 .14 .036$

Wacana (7) dan (8) menggambarkan bagaimana kelompok atas memperhatikan pakaian (fashion) mereka sehari-hari. Wacana pertama ditujukan kepada para wanita yang ingin tampil formal. Wacana tersebut memberikan alternatif bagi wanita memiliki tubuh lurus tidak pinggang (boyish). Oleh karena itu, hadirlah istilah boyish style. Istilah boyish style adalah paduan gaya pria dan wanita yang diaplikasikan dalam cara berpakaian wanita. Namun, perpaduan gaya berpakaian dua gender itu masih menonjolkan sisi feminin seorang wanita yang mengutamakan kecantikannya.

Wacana kedua hadir untuk para wanita yang ingin tampil menarik dengan menggunakan motif polkadot. Motif ini adalah motif bintik-bintik pada pakaian, dompet, atau sepatu. Agar tampil seksi dengan motif polkadot, pembaca bias mencoba menggunakan blus cropped dengan rok model terompet yang menonjolkan area pinggul. Selain itu, pembaca disarankan untuk menggunakan jumpsuit motif polkadot untuk menghindari kesan kekanakan.

Kedua wacana di atas adalah kebiasan kelompok kelas atas dalam hal berpakaian. Rubrik mode dan cantik menampilkan habitus tersebut. Ketika kelompok kelas bawah membaca rubrik tersebut, mereka dapat saja menirunya. Mereka dengan suka rela mengikutinya. Inilah yang disebut sebagai kekerasan simbolik.

\section{Wacana Kecantikan yang Berorientasi pada Model Internasional}

Kelas-kelas sosial yang berbeda akan mempengaruhi cara berpakaian atau merawat kecantikan mereka. Bagi kelompok atas, orientasi kecantikan bagi kelompok atas adalah model atau aktris internasional. Mereka meniru hal-hal yang dilakukan oleh model atau artis internasioal, misalnya dalam hal kecantikan.

(9) Saat mengenakan busana semiformal Jessica Biel memilih riasan smoky eyes. Perona mata warna hijau tosca atau biru yang segar menjadi pilihan. Oleskan perona pipi dan lipstick cokelat muda.

19-25.07.14.066

(10) Warna ungu dapat menciptakan riasan mata tampak beda. Scarlett Johansson memadankannya dengan tataan up do yang menawan. Buatlah gradasi warna ungu pada kelopak mata agar terhindar dari kesan mata seperti hitam.

19-25.07.14.067

(11) Pemilik kulit gelap, coba gunakan eye shadow seperti dikenakan Kerry Washington yang mengoleskan eye shadow warna silver metalik dengan highlight putih. Ingin tampil lebih keren? Pulaskan 
lipstick warna shocking orange yang sedang digemar.

$19-25.07 .14 .068$

Wacana (9), (10), dan (11) menunjukkan bahwa orientasi kecantikan golongan kelas atas adalah model atau artis internasional. Jessica Biel adalah seorang aktris dan mantan model fashion Amerika Serikat. Ia terkenal karena muncul dalam beberapa film Hollywood seperti Summer Catch, pembuatan kembali The Texas Chainsaw Massacre, dan The Illusionist, dan juga peran televisinya sebagai Mary Camden dalam serial 7th Heaven. Jessica Biel juga istri penyanyi terkenal, yaitu Justin Timberlake. Scarlett Johansson adalah seorang aktris dan penyanyi dari Amerika Serikat dan Kerry Washington juga seorang aktris kebangsaan Amerika Serikat. Ketiga wacana di atas menunjukkan kebiasaan kelas atas yang meniru cara para artis Amerika Serikat dalam merawat kecantikannya.

\section{PENUTUP}

Mekanisme kekerasan simbolik dilakukan secara halus melalui berbagai macam wacana sehingga korban kekerasan simbolik tidak terlihat seperti korban kekerasan fisik. Wacana dalam sebuah rubrik bukanlah wacana yang alamiah karena didalamnya ada kepentingan kekuasaan (ekonomi). Wacana yang diproduksi mengandung maksud-maksud tertentu. Ada wacana-wacana yang memang sengaja dibuat oleh kelompok kelas atas atau pemilik modal untuk berbagai macam kepentingan. Wacana untuk kepentingan tertentu berpotensi menjadi kekerasan simbolik. Ada beberapa wacana yang berpotensi menjadi bentuk kekerasan simbolik pada rubrik mode dan cantik majalah Femina, yaitu wacana tentang: 1) gaya hidup konsumtif, 2) penggunaan barang-barang bermerek, 3) memperhatikan penampilan: wajah dan gaya berpakaian, dan 4) orientasi kecantikan pada model internasional.

\section{UCAPAN TERIMA KASIH}

Artikel ini diangkat dari penelitian yang telah dilakukan pada tahun 2014 dengan anggaran DIPA UNY. Oleh karena itu, ucapan terima kasih kepada ketua BPPF yang telah menyetujui dan mendanai penelitian ini. Ucapan terima kasih juga disampaikan kepada kedua orang review yang telah membaca, mengoreksi, dan memeberi masukan terhadap artikel ini.

\section{DAFTAR PUSTAKA}

BBC Indonesia. 2012. "Pemuda Jual Ginjal Demi iPad dan iPhone." Diunduh pada tanggal 10 Februari 2014 dari http://www.bbc.co.uk/indonesia/ majalah/2012/04/120407_ipadkidney. shtml

Caloguori, Caludio. 2010. "Symbolic Violence and the Violation of Human Rights: Continuing the Sociological Critique of Domination." International Journal of Criminology and Sociological Theory. Vol. 3, No. 2, Juni 2010, halaman 388400.

Djajasudarma, T. Fatimah. 2006. Metode Linguistik Ancangan Metode Penelitian dan Kajian. Bandung: Reflika Aditama.

Eriyanto. 2006. Analisis Wacana Pengantar Analisis Teks Media. Yogyakarta: LKIS.

Gumperz, John J. 1982. Discourse Strategies. Cambridge: Cambridge University Press.

Harahap, Machyudin Agung. 2013. Kapitalisme Media Ekonomi Politik dan Diskursus Televisi. Yogyakarta: Aura Pustaka.

Mahsun. 2005. Metode Penelitian Bahasa: Tahapan Strategi, Metode, dan Tekniknya. Jakarta: PT Rajagrafindo Persada.

Mark \& Spencer, Brand Fashion Berkelas. 2012. Diunduh pada tanggal 16 September 2014 dari http://www.vemale.com/ brand/15822-marks-spencer-brandfashion-berkelas.html.

Martono, Nanang. 2012. Kekerasan Simbolik di Sekolah Sebuah Ide Sosiologi Pendidikan Pierre Bourdieu. Jakarta: Raja Grafiindo Persada.

Rezkisari, Indira. 2014. "Perempuan Gunakan Barang Mewah untuk Usir Perempuan Lain”. Diunduh pada tanggal 14 Agus- 
tus 2014 dari http://www.republika. co.id/berita/humaira/samara/14/02/21/ n1cc4l-perempuan-gunakan-barangmewah-untuk-usir-perempuan-lain.

Roekhan. 2010. "Kekerasan Simbolik di Media Massa." Jurnal Bahasa dan Seni. Tahun 38, nomor 2, Agustus 2010, halaman 253-265.

Sudaryanto. 2001. Metode dan Aneka Teknik Analisis Bahasa. Yogyakarta: Duta Wacana University Press.

The Executive. 2012. Diunduh pada tanggal 16 September 2014 dari http://www.vemale.com/brand/15932-the-executive. $\mathrm{html}$
Mellisa, Cindy. 2014. "Label Busana Stradivarius Buka Cabang di 60 Kota di Amrik". Diunduh pada tanggal 16 September 2014 dari http://lifestyle.liputan6.com/ $\mathrm{read} / 2058801 /$ label-busana-stradivarius-buka-cabang-di-60-kota-di-amrik.

Wahyu. 2013. "Kata Mungkin Tidak Pernah Ada dalam Kamus Femina Group." Diunduh pada tanggal 19 Februari 2014 dari http://media.kompasiana. com/mainstream-media/2013/10/04/ kata-mungkin tidak-pernah-ada-dalamkamus-femina-group-595559.html 